\title{
Die Ansprechpartnerinnen und Ansprechpartner der DMV
}

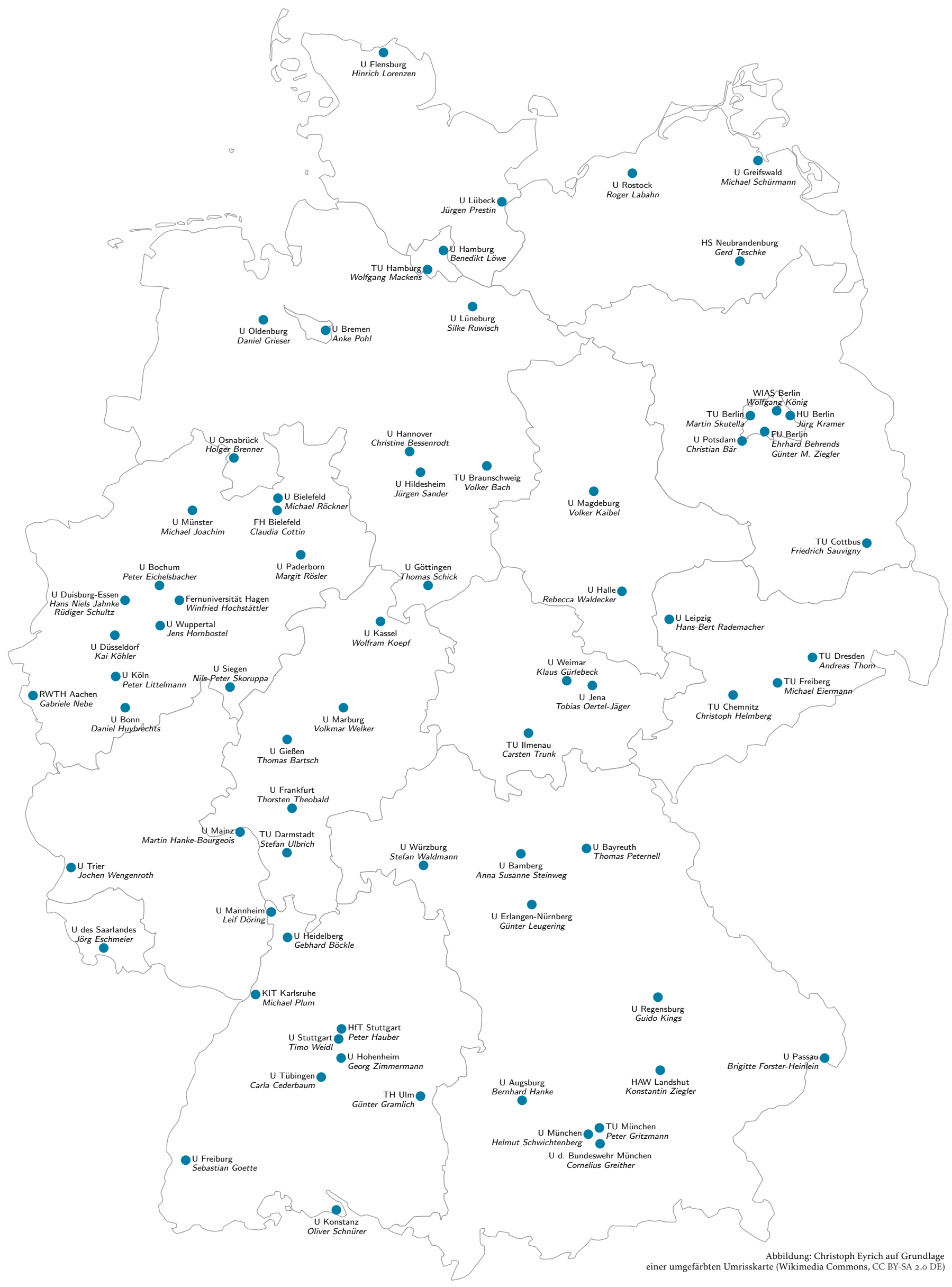

